\title{
Assessment of depression in people with diabetes attending outpatient clinics for the treatment of foot ulceration
}

\author{
Toni Nash ${ }^{1 *}$, Vanessa Ireland ${ }^{1}$, Sue Pearson ${ }^{2}$ \\ From Australasian Podiatry Council Conference 2013 \\ Sydney, Australia. 2-5 June 2013
}

\section{Background}

People with diabetes and foot ulceration experience more depressed mood particularly when healing does not occur after prolonged treatment. Those who have depression and diabetes have poorer adherence to selfcare or treatment regimes, poor glycaemic control along with a greater risk of diabetes related complications and mortality. Screening for depression has been shown to be effective to determining the severity of depression as well as the type of treatment required.

\section{Methods}

The study required participants to complete a validated self-reporting 9 item Patient Health Questionnaire (PHQ) that provides a diagnosis of major depressive syndrome and continuous severity score. Participants were classified in the depressed category if they had PHQ score $\geq 5$. Group differences were examined using chisquare for categorical variables and $t$-tests for continuous variables.

\section{Results}

A higher proportion of participants had diabetes for $>10$ years, however no other demographic variables were associated with depression. Of the 60 participants, 31 (51.7\%) were categorised as depressed, with $10(17 \%)$ having had a prior diagnosis of depression and 21 (35\%) participants had unrecognised cases of depression.

* Correspondence: toni.nash@dhhs.tas.gov.au

'Southern Tasmanian Area Health Service, Hobart, Tasmania, Australia

Full list of author information is available at the end of the article

\section{Conclusion}

This study demonstrated the prevalence of depression in people with diabetes and the often hidden impact it has in managing diabetes foot ulceration.

\section{Author details}

'Southern Tasmanian Area Health Service, Hobart, Tasmania, Australia. 2University of Tasmania \& Menzies Centre, Hobart, Tasmania, Australia.

Published: 31 May 2013

doi:10.1186/1757-1146-6-S1-028

Cite this article as: Nash et al: Assessment of depression in people with diabetes attending outpatient clinics for the treatment of foot ulceration. Journal of Foot and Ankle Research 2013 6(Suppl 1):O28.

\section{Submit your next manuscript to BioMed Central and take full advantage of: \\ - Convenient online submission \\ - Thorough peer review \\ - No space constraints or color figure charges \\ - Immediate publication on acceptance \\ - Inclusion in PubMed, CAS, Scopus and Google Scholar \\ - Research which is freely available for redistribution \\ Submit your manuscript at www.biomedcentral.com/submit}

